\title{
The future of the hydro-generated metropolis: new projects for at-risk cities on the water
}

\author{
N. Clark \\ University of Florida School of Architecture, USA
}

\begin{abstract}
Due to an inattention to the impact of human settlement patterns on the hydroecologies of many cities on water, the contemporary urban project often involves undoing the legacies of these past relationships while wrestling with the resultant environmental problems of the present. It is also our future and the inevitability of environmental changes that demands rethinking development of cities on water. Nearly $1 / 4$ of the world's population lives within $100 \mathrm{~km}$ distance of the coast and over the next several decades we will see a continued surge in urbanization, much of it set to occur in coastal cities. This paper will explore new paradigms for water based settlements through a study of urban interventions on the Florida Atlantic Intracoastal Waterway. Historically Florida has been bold with its approach to creating and adapting hydro landscapes; from the desiccation of the everglades and the canalization of its interior to the feat of the Intracoastal Waterway itself. Our project builds upon these daring cultural landscapes of our past tempered with hindsight about the need for environmental stewardship and the use of natural values to improve urban health, the quality of life, and urban equity.

Keywords: coastal cities, urban development, climate change, environment, urban planning, urban governance, waterways, community, planning for risk, waterfront development.
\end{abstract}

\section{Introduction}

Cities around the globe are confronting the consequences of prior settlement patterns and an inattention to their hydro-ecologies. Urban growth and industrialization has stood as the transformational force in the often conflictual relationship between urban development and water in the city. Consequently, the contemporary urban project often involves undoing the legacies of these past 
relationships while wrestling with the resultant environmental problems of the present such as pollution, flooding, health risks, and land degradation. Of course, it is not only our past but also our future and the inevitability of environmental and climate changes that requires rethinking current modes of the development of cities on water. Currently, $23 \%$ of the world's population lives within $100 \mathrm{~km}$ distance of the coast and $60 \%$ of the world's 39 metropolises with a population of over 5 million are located within $100 \mathrm{~km}$ of the coast, including 12 of the world's 16 cities with populations greater than 10 million [1]. Over the next several decades we will see a continued surge in urbanization and much of it is will occur in coastal cities. All of this demands a reconceptualization of the hydro-metropolis and a shift in our perspective about the influence of natural components in the future and recovery of urban areas. The place and purpose of the hydro environment in society and the metropolis is changing and cities are exploring new ways of valuing and understanding what it means to live in the midst of land and water by asking fundamental questions about what roles urban waterways can have in the process of urbanization and urban regeneration in the $21^{\text {st }}$ century. This revised relationship with the environment also requires new ways of planning, designing, and governing.

Florida is particularly vulnerable to water fluctuations. The state is ranked first out of the top ten nationally ranked states, counties and cities for largest total populations living on land less than four feet above local high tide, with half of the total exposed population and 8 of the 10 most vulnerable cities in the US. Using conservative numbers, this translates into over 600,000 acres of current dry land predicted to be under water by 2050 [2]. Furthermore, it is projected that by 2070 Miami will rank $9^{\text {th }}$ in the world for population exposed to coastal flooding and $1^{\text {st }}$ in the world for flood vulnerable assets [3].

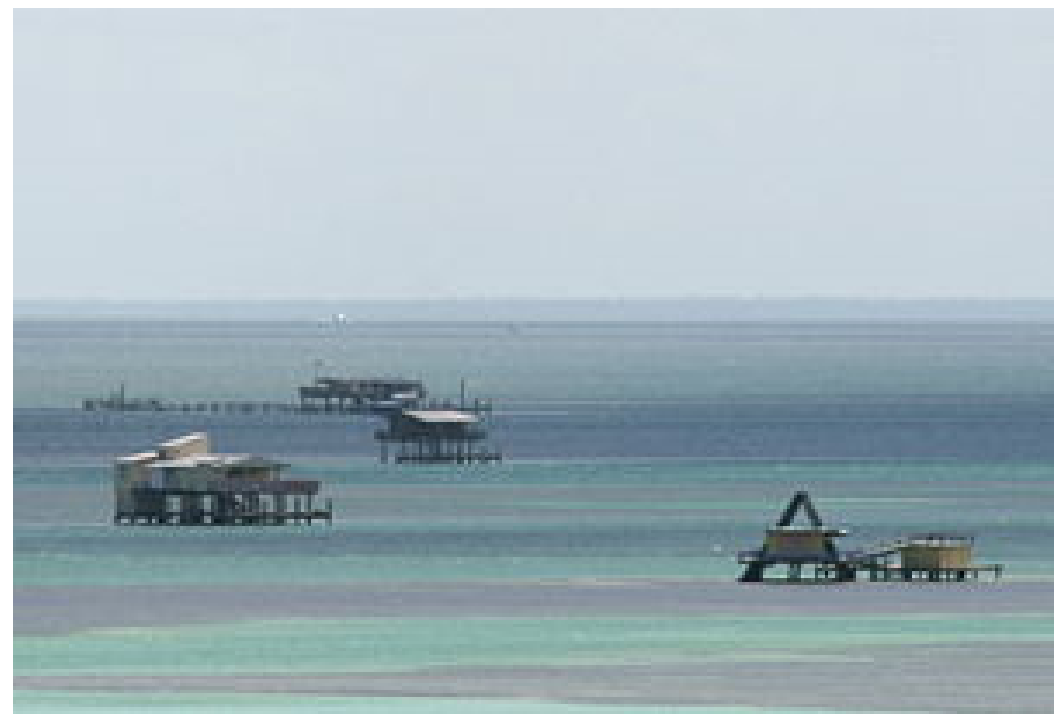

Figure 1: View of Stiltsville: a water settlement off the coast of Florida. 


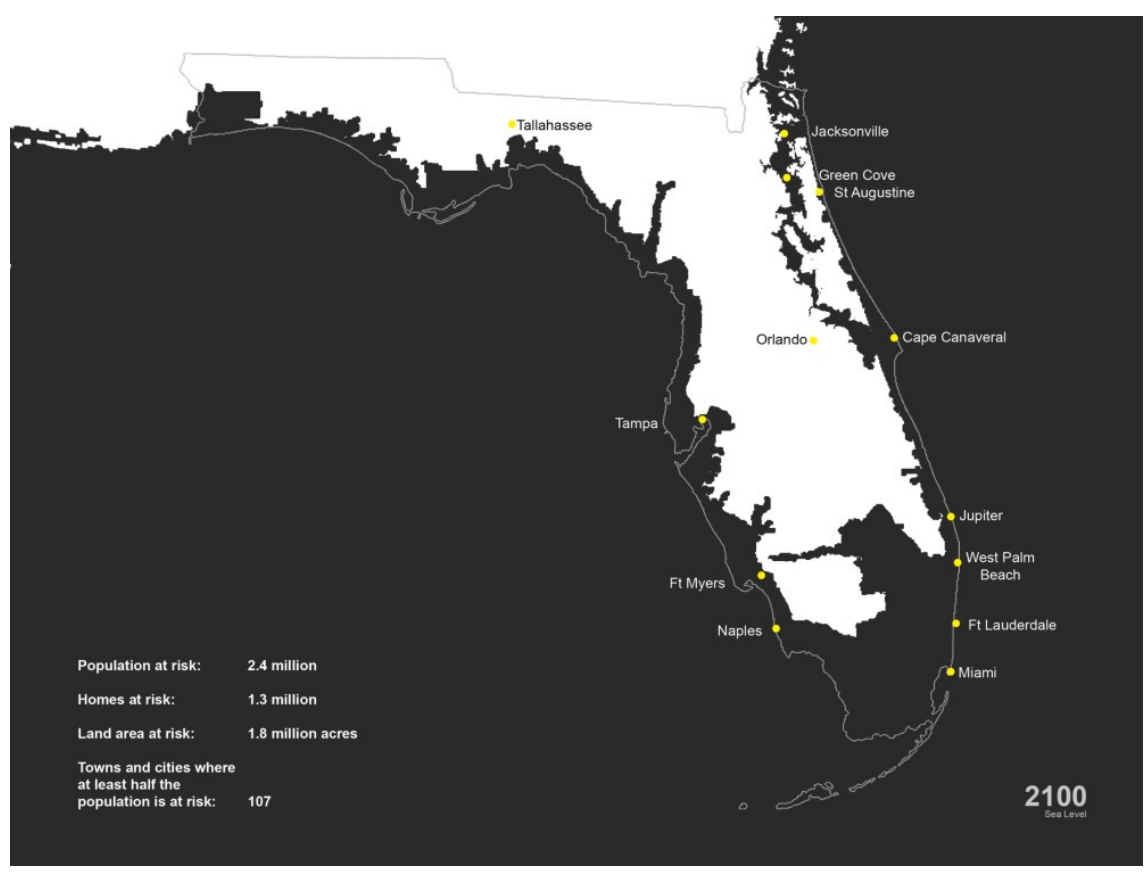

Figure 2: $\quad$ Land mass State of Florida c. 2100.

With over 2,000 $\mathrm{km}$ of coastline surrounding the peninsula, rising tides are an obvious concern for Florida. Coastal communities and tidal habitats will be increasingly stressed by the interaction of climate change impacts with development and population growth. However, much less known is the impact of Florida's karst topography on the interior of the state. Florida has a porous underground geological substrate made of limestone which acts like a sponge. As we have continued to drain the fresh water aquifer below us and the wetlands surrounding us, ground water level has risen and sea water has filled the gap from below creating saltwater intrusion as well as the subsequent and inevitable inland inundation and flooding. Consequently, many strategies that are being considered in other at-risk locations such as New York City and the Netherlands will not work for Florida. Dikes and flood gates will not stop the water. Furthermore, in regions with low lying inland areas, especially in the southern region of the state, retreat will not necessarily resolve the situation either. Clearly, adaptation in large portions of Florida will require future development to elevate.

In response, we propose a series of redevelopment projects, set along the 400 miles of coastline of the Florida Atlantic Intracoastal Waterway, that attempt to shape these facts into an opportunity to envision and to build an environmentally viable urban future for these cities. Each project proposes an innovative hydroinfrastructure that not only mitigates these environmental concerns but also performs a productive function in the re-visioning of each urban territory set in its new relationship to the water. For better or for worse, historically Florida has been 
bold with its approach to creating and adapting hydro landscapes; from the desiccation of the everglades and the canalization of its interior to the feat of the Intracoastal Waterway itself. Our research builds upon these daring cultural landscapes of our past tempered with hindsight about the need for environmental stewardship and the use of natural values to improve urban health, the quality of life, and urban equity.

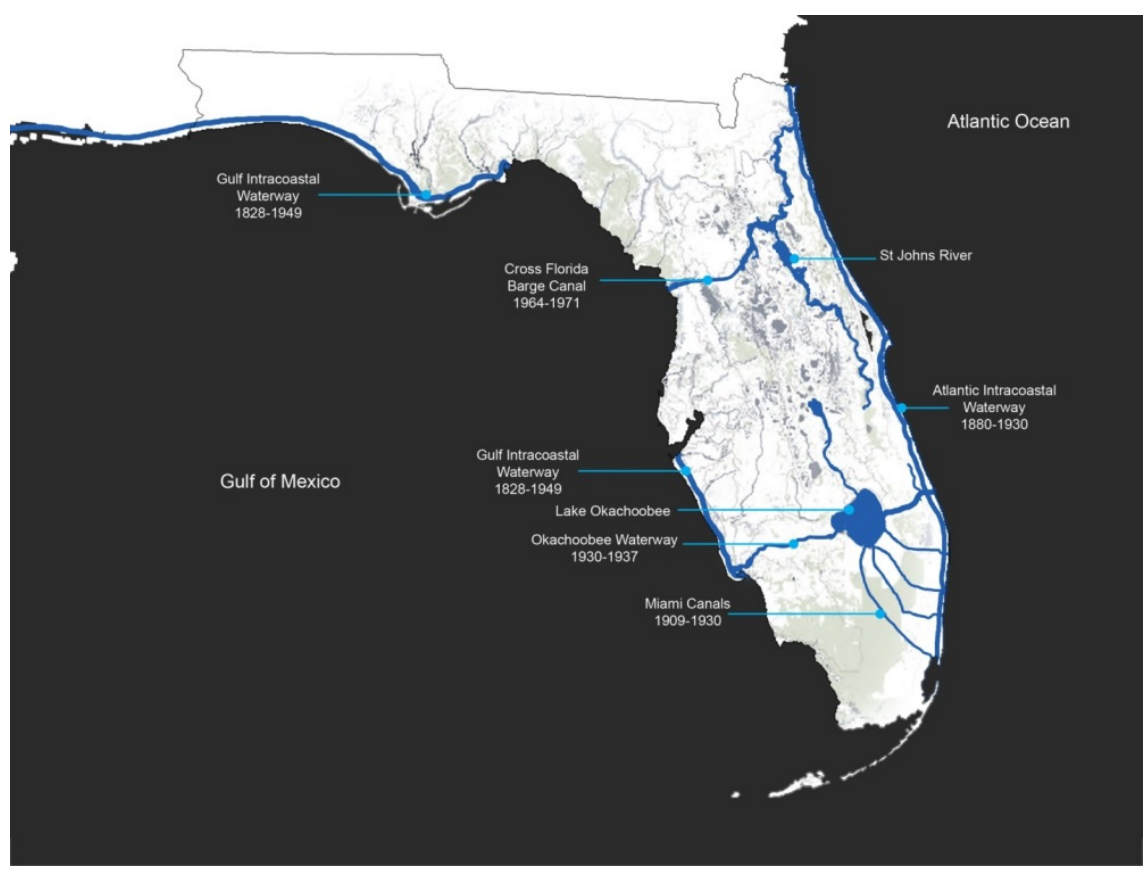

Figure 3: Major water infrastructural projects in Florida.

The one crucial factor that would affect Florida's future development more than anything else over the course of its history was the federal government's possession of 20 million acres - nearly $2 / 3$ of the state's land area - designated by the government as "swamp and overflow land". In the 1850 s, in accordance with the Internal Improvement Act, the federal government began to grant the new state of Florida millions of acres of swamp lands to encourage improvements such as drainage and reclamation. This set the stage for metropolitan and industrial expansion of Florida. Over the following 30 years, the state's population grew $210 \%$ from 87,000 to 270,000 [4]. As a result of this massive effort to remake its environment, much of Florida's terrain and hydrology is artificial. The landscape south of Lake Okeechobee is a completely engineered environment, modified in the beginning of the $20^{\text {th }}$ century with canals, levees and dikes. What was once a "river of grass" and - what we now know - a vital hydrological ecology became agricultural land and urbanized areas [5]. Further north, the unfinished Cross Florida Barge Canal began with aspirations to connect the Gulf of Mexico and the 
Atlantic Ocean across Florida as a protected and economical route for barge and boat traffic. At 200 miles long and 30 feet deep, it would have dwarfed the Suez and the Panama Canal and required significant alteration of 3 pristine rivers [6]. The natural landscape was also reworked along the coastline with the construction of the Florida Intracoastal Waterway, a protected navigable route made of natural inlets, saltwater rivers, bays, and sounds as well as artificial canals encircling the state. Running in parallel with the railway along the Atlantic Ridge, a geological formation that evidences the cycles of the coasts ebb and flow over millions of years, the Atlantic inland waterway is a feat of engineering and audacity. It spurred settlements along its length and to the west where entire cities emerged out of wetlands and acres of artificial islands were created for development.

With the Florida Atlantic Intracoastal Waterway as our context, we are exploring possibilities of future development along the east coast with an emphasis on increased density and proposing innovative settlement patterns. Our research aspires to craft new and versatile systems of urban planning that reconcile the concerns of the environmental with the need for new and vital urban places. Our intention is to raise awareness about the future hydro environment of Florida through project based research that can serves as a catalyst for action. We are investigating the potential relationships between new systems of coastal planning, environmental stewardship, and metropolitan life and, throughout the process; we have looked to the historical precedents of Florida's urban environments spawned through a territorial manipulation of the aquatic systems. This research also includes speculations on the environmental and economic future of Florida's waterways through topics such as the state of infrastructure Post-Panamax, continued population growth, as well as Florida's ever changing coastline. What follows are a series of propositions that frame the need to "elevate" in terms of community infrastructures and neighborhood ecologies.

\section{Podium city: adapting the coastal skyline}

There are currently thousands of residential condominium towers lining Florida's beaches and Intracoastal Waterways with more being constructed each year. Potential buyers are not required by law to be alerted to the properties at risk status. As sea level rises, by mid-century the lower floors of these structures could be submerged, calling into question the validity of an owner's 30 year mortgage. There is no doubt this real estate is as idyllic as it is expensive. Rather than displacing whole communities, we propose constructing a new podium infrastructure connecting the towers and creating an artificial ground for "street level" activities to occur. This new urban-scape infrastructure will serves as the primary means for mobility along the newly created islands as the natural coastlines recede inland. Florida settlement pattern along the beach is emblematic of many beach cities nationally and internationally. We believe this concept is portable and could be employed in other coastal cities around the globe where the condo tower typology is prevalent. 


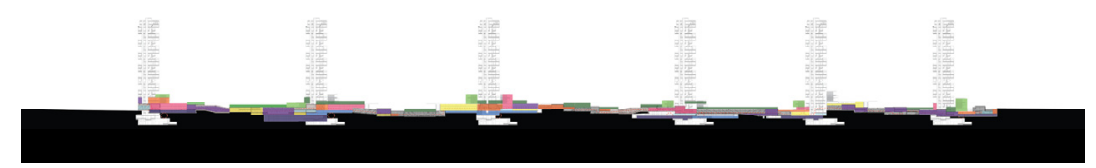

Figure 4: Section diagram showing linking podium infrastructure.

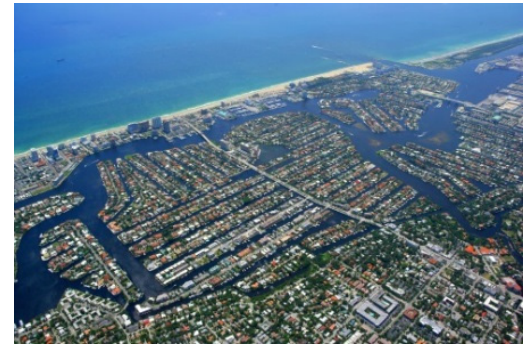

Figure 5: Views of artificial island development.

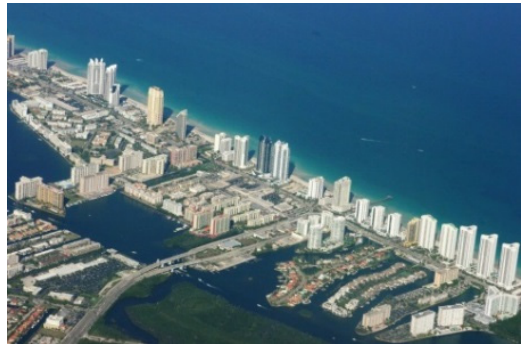

Figure 6: Towers lining the coastal barrier island.

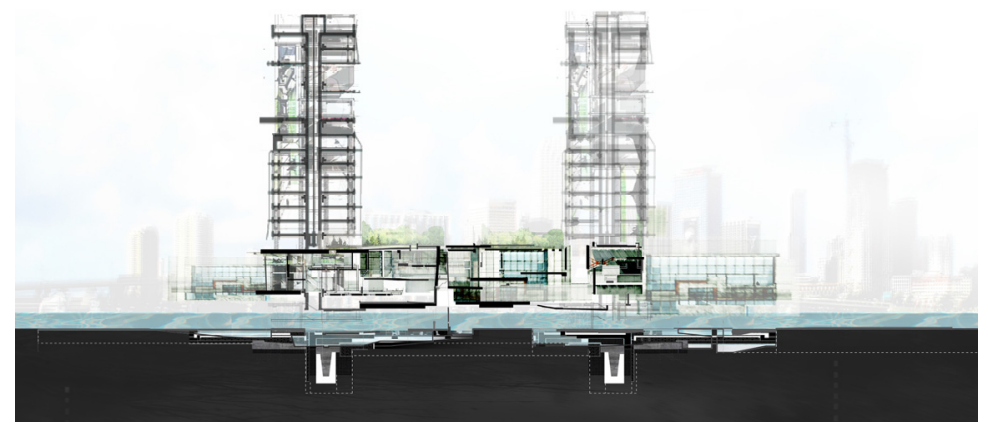

Figure 7: Section detail of floodable towers and new podium infrastructure.

\section{Retrofitted city: repurposing territories}

Along the northeast Florida coast, approximately 30\% of the areas land is vulnerable at a 3 foot rise of sea level and potentially one half million people will be affected based on current population numbers [7]. The St. Johns River will become an important protected deep water route as the coastline recedes and the Intracoastal Waterway is exposed. The town of Green Cove Springs sits along the river just south of Jacksonville and west of historic St. Augustine. It is home to a hydrological springs and was a popular tourist destination in the $19^{\text {th }}$ century. The town was established as a military base in the 1940s to house naval destroyer vessels. The base was decommissioned in 1960 and the thirteen 1,800 foot long 
piers remain abandoned. We propose retrofitting this existing vacated facility into a new urban core development for the environmental migrants that will be moving inland from inundated coastal cities nearby and for newcomers that will continue to flock to Florida. The regeneration of Green Cove Springs is intended as a prototype to be used as a model for identifying new development opportunities, recycling post-industrial sites and vacated military facilities into new communities for displaced populations in other susceptible existing urban areas.

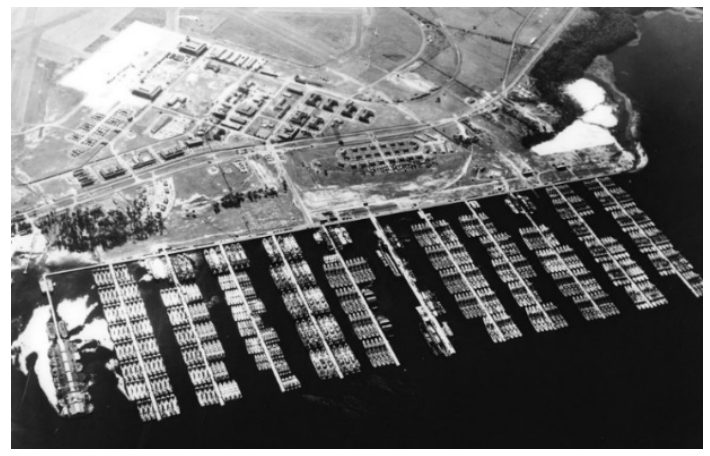

Figure 8: Green Cove Springs military naval base.

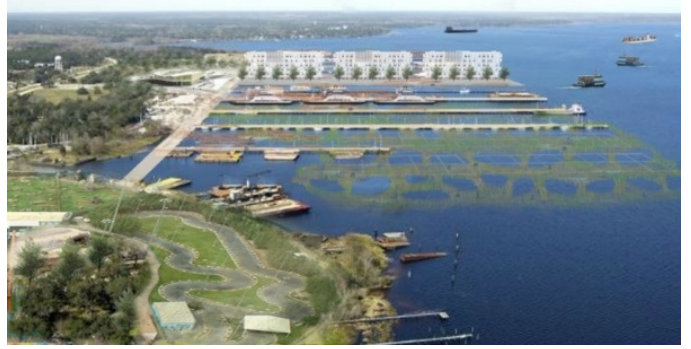

Figure 9: Green Cove Springs City c. 2030.

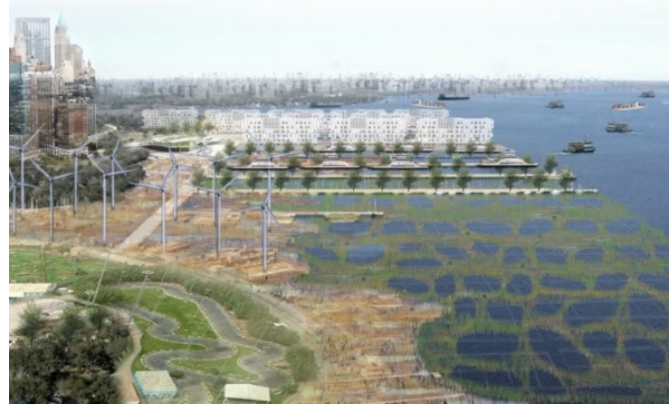

Figure 10: Green Cove Springs City c. 2100. 


\section{Barrier city: protecting heritage settlements}

Although armouring large territories in Florida is not a viable option due to circumstances of geology and scale, it will be necessary to identify specific strong holds that do need to be defended. These places could have cultural and historical value or have community and governmental importance as investment assets. We believe one such place is St. Augustine Florida, the oldest city in the US and home to the national monument Castillo de San Marcos. The city is located in the 100,000 acre Matanzas Basin, which runs from Anastasia Island to Crescent Beach and, according to predictions, in St. Augustine alone over one thousand acres of developed and undeveloped dry land will become a salt marsh by 2075 [8]. Our proposal identifies limited but key areas in the city to fortify with sea walls and dikes including Castillo de San Marcos and the small historic downtown area and allows for shoreline retreat for the remaining land at risk. These protected areas will become islands over time as the natural coastal processes occur and the riparian, littoral and aquatic wetland systems claim the environment surrounding them. We propose that Barrier City and Retrofitted City are directly linked as complimentary strategies with climate refugees relocated to the new urban core.

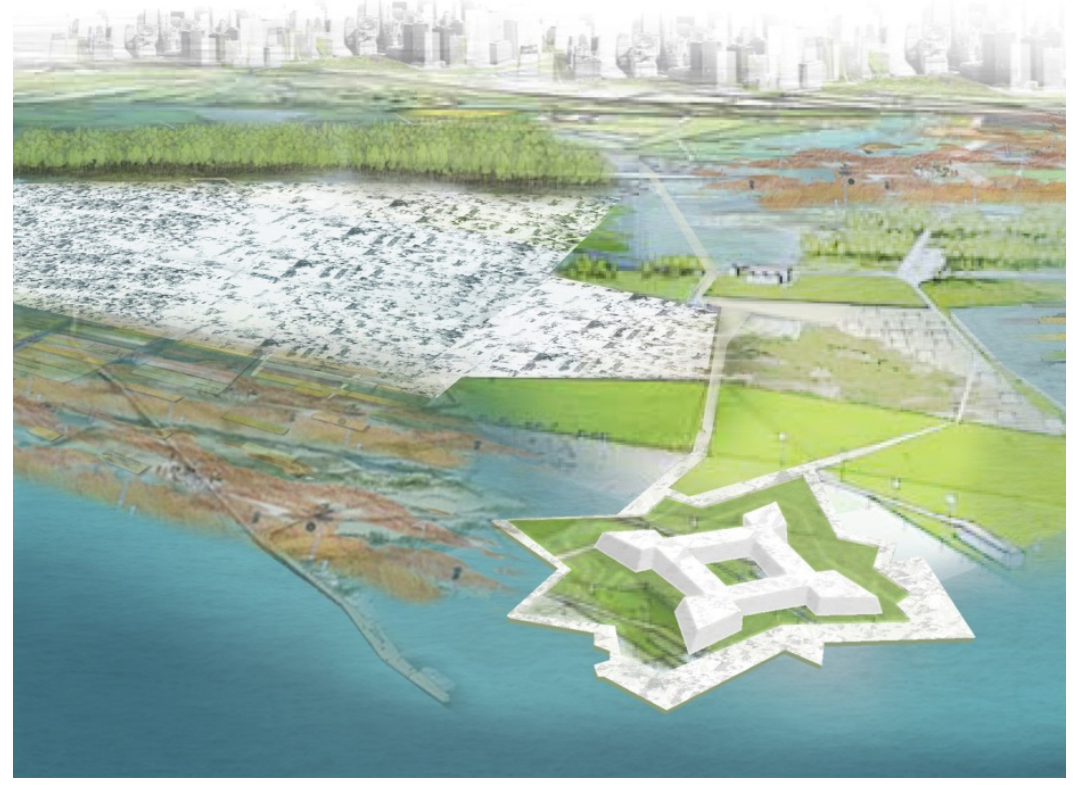

Figure 11: St. Augustine c. 2100 with Castillo de San Marcos in foreground and new urban core in beyond.

\section{Archipelago city: colonizing the aquatic edge}

The barrier islands that characterize Florida are extensive and are valuable resources that provide sensitive coastal habitats and ecosystems, and protect the 
marshes and coastal estuaries during storms. Over the past three decades, these natural and man-made islands have become densely developed. Many of these protective landscapes will be lost as the water level rises. Archipelago City proposes protecting some of these more heavily populated barrier islands with an inhabitable artificial reef infrastructure. Based on floating cities of the past as well as Florida's own examples of aquatic settlements such as Stilt City, this project will secure and defend new patterns of connectivity in the formation of keys. The reefs are created with prefabricated modules utilizing marine technology and connected with wave attenuation platforms. These modules can be assembled in various patterns and scales to form a new settlement prototype. Over time, harbour communities are created along the coast of Florida. This infrastructural strategy has the potential to protect a significant amount of urbanized barrier coastal areas.

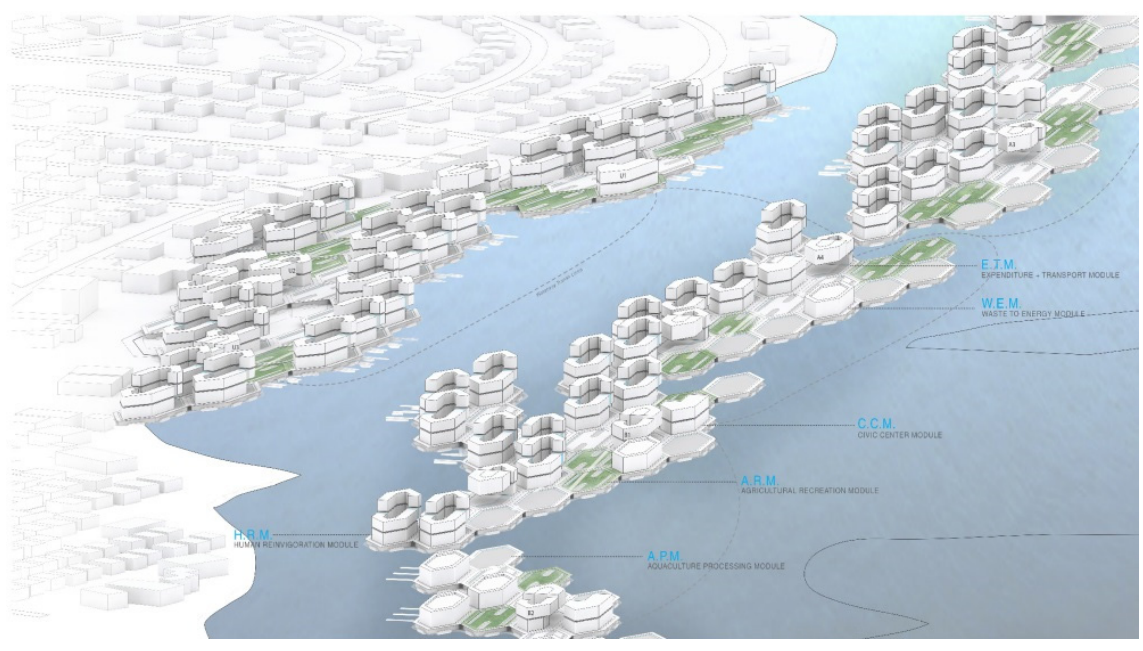

Figure 12: Artificial barrier reef colony.

\section{Elevated city: founding a multi-layered coastal settlement}

Cape Canaveral is home of the Kennedy Space Center established in 1960s and the former hub of the nation's human space program. This is where astronauts conquered the moon and, as such, it remains an iconic place for our nation and perhaps the world. The area is under conversion and is a strategic location for increased development. Our proposal captures opportunities that are emerging out of Post-Panamax port development. Port Canaveral is already a thriving cruise port of Orlando and with the influx of funding to upgrade the port size, it is also rapidly expanding to become one of Florida's major container ports. Elevated City is new water based settlement on a raised mega infrastructural platform. It is also an artificial land bridge connecting the city of Orlando with this new coastal city through railway and interstate links. The development will be built in phases, growing to accommodate the increasing density from displaced inhabitants below. 
The project is composed of three levels. The first and lowest level incorporates water activities and serves to connect the land and water below to the city above. The second level contains public transport and other mobilities and the uppermost level is the main city center with all the amenities necessary for living, work and recreation.

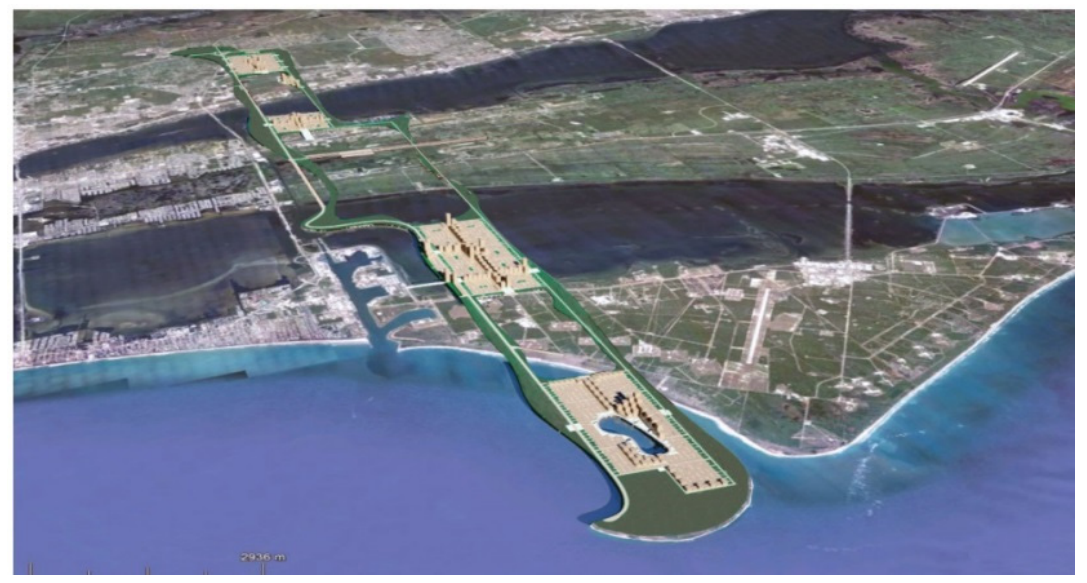

Figure 13: Aerial rendering of Cape Canaveral elevated city.
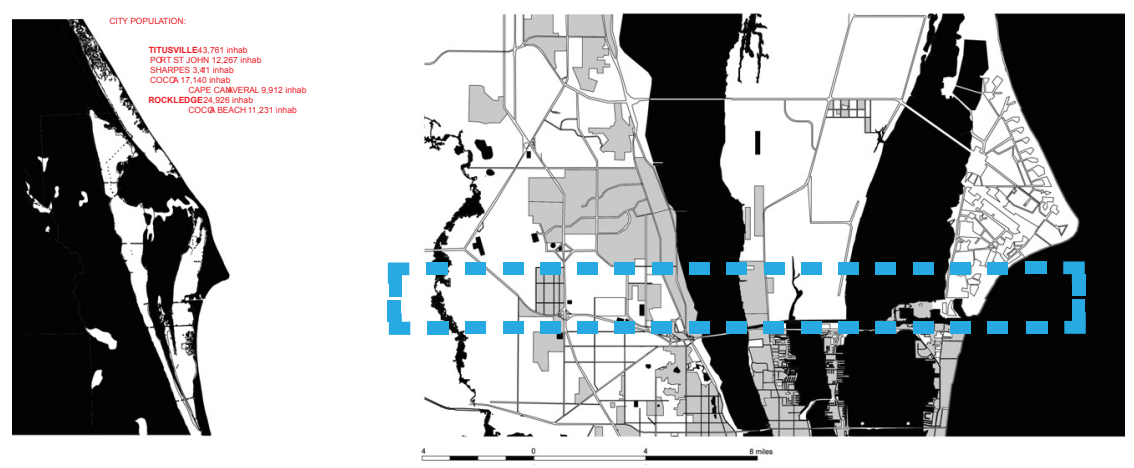

Figure 14: Map showing area of elevated city (dashed in blue).

\section{Conclusion}

The five scenarios presented here are a part of our on-going speculations about the hydro-urbanism of Florida and the future of its waterway cities. (The ongoing research presented here is in collaboration with Professor Martha Kohen and graduate students from the University of Florida.) These propositions imagine new communities that are responsive to new environmental conditions in the face of Florida's continuing urbanization. Ultimately, they should be understood as strategies that explore the design challenges and opportunities of an elevated urbanism for a sinking Florida. 


\section{References}

[1] M.L. Parry, O.F. Canziani, J.P. Paulutikof, P.J. van der Linden and C.E. Hanson (eds.), Climate Change 2007: Working Group II: Impacts, Adaptation and Vulnerability Section 6.2.2 Increasing Human Utilisation of the Coastal Zone, Contributions of Working Group II to the Fourth Assessment Report of the Intergovernmental Panel on Climate Change, 2007, Cambridge and New York.

[2] Nicholls, R.J, Hanson, S., Herweijer, C., Patmore, N., Hallegatte, S., Jan Corfee-Morlot, Jean Chateau and Muir-Wood, R., Table 1: Top 20 Cities Ranked in Terms of population exposed to coastal flooding 2070, Ranking of the World's Cities Most Exposed to Coastal Flooding Today and in the Future: Executive Summary, OECD 2007, p. 5.

[3] Surging Seas Sea Level Rise Analysis by Climate Central Surging Seas Fact sheets, March 14, 2012, http://sealevel.climatecentral.org/research/reports/ surging-seas-state-factsheets

[4] Florida Historical Census Counts, UF, Bureau of Economic Business Research, Online http://www.bebr.ufl.edu/files/Hist_Census_Counties_2.pdf

[5] The nickname "River of Grass" often associated with the Everglades originated from a book title "The Everglades: River of Grass" by Marjory Stoneman Douglas published in 1947.

[6] Noll, Steven and David Tegeder, Ditch of Dreams, (Florida: University of Florida Press, 2009).

[7] Frank, Kathryn and Dawn Jourdan, Planning for Sea Level Rise in the Matanzas Basin: A Closer Look Community Environment and Legacy, February 24 2014, pp. 18-27. Online http://gtmnerr.org/CTP-Sea-LevelRise.php

[8] Nelson, Brian, "Rising Sea Levels are Impacting St. Augustine", 1565 Today.com, December 7, 2012. Interview of Dr. Kathryn Frank, University of Florida about a three study being conducted by the College of Design Construction and Planning with the National Estuarine Research Reserve System Science Collaborative funded by the University of New Hampshire. 